\title{
One Size Does Not Fit All - Understanding The Front-End And BACK-END OF BUSINESS MODEL INNOVATION ${ }^{1}$
}

\author{
Franziska Günzel \\ Business and Social Sciences, Aarhus University \\ Bartholins Allé 10, 8000 Aarhus C \\ Denmark \\ E-mail: $\underline{\text { rang@asb.dk }}$ \\ Anna B. Holm \\ Business and Social Sciences, Aarhus University \\ Bartholins Allé 10, 8000 Aarhus C \\ Denmark \\ E-mail: annah@asb.dk
}

\begin{abstract}
Business model innovation is becoming increasingly a central research topic in management. However, a lack of a common understanding of the nature of the business model leads to disregarding its multifaceted structure when analysing the business model innovation process. This article proposes a more detailed understanding of the business model innovation process by drawing on existing knowledge from new product development literature and examining the front-end and the back-end of business model innovation of three leading Danish newspapers. We studied how changes introduced during the development of digital news production and delivery have affected key components of these business models, namely value creation, proposition, delivery and capture in the period 20022011. Our findings suggest the need to distinguish between front-end and back-end business
\end{abstract}

\footnotetext{
${ }^{1}$ Preprint of the article published in International Journal of Innovation Management, Volume 17, Issue 1, 2013, DOI 10.1142/S1363919613400021, @ Copyright World Scientific Publishing Company, Article URL: http://www.worldscientific.com/doi/abs/10.1142/S1363919613400021
} 
model innovation processes, and to recognise the importance of organizational learning and choice when incumbents are faced with disruptive technologies.

Keywords: business model, business model innovation, innovation process, newspaper industry, new product development literature, online publication, disruptive technology, back-end innovation, front-end innovation.

\section{Biographical notes:}

Dr. Franziska Günzel is a Post.Doc. at the Department of Business Administration, Business and Social Sciences, Aarhus University, Denmark. She has a PhD (2011) in entrepreneurship from the Otto von Guericke University Germany, and a Diploma in International Management (2007) from the Ocean University Qingdao, China . Dr. Günzel's research focuses on business model analysis and design, qualitative methods, entrepreneurship, innovation in health care delivery, and decision analysis. Prior to her $\mathrm{PhD}$, Dr. Günzel worked in both the private and academic sectors, with stints in China and Singapore.

Dr. Anna B. Holm is Assistant Professor at the Department of Business Administration, Business and Social Sciences, Aarhus University, Denmark. She has a $\mathrm{PhD}$ (2010) in organization and management theory from Aarhus University, and an MBA (1995) from the Bradford University School of Management, UK. Dr. Holm's research area includes virtual organizing, business model design, and electronic human resource management (e-HRM). Prior to her academic career, Dr. Holm worked for over a decade as a business development consultant and in various managerial positions in industry.

Acknowledgement: This research has been funded by the Danish Council for Strategic Research, 09-063245, (Digital Urban Living). We would like to thank several members of 
staff from Berlingske Media and JP / Politikens Hus for their generous assistance and contribution to this research. Last, but not least, we wish to gratefully acknowledge the assistance Anastasia Uliyanova provided in collecting additional data. The usual disclaimer applies. 


\section{INTRODUCTION}

Business model innovation is becoming increasingly a central subject of research and practice in management as many companies seek to achieve a competitive advantage through business model innovation (Amit and Zott, 2012). As a process, and not merely a management concept, business model innovation encompasses developing novel value chain architectures in different ways, from new product developments to new delivery and marketing patterns, as well as innovative resource acquisition and application (Chesbrough, 2010). The novelty presented by new business models can potentially result in superior value creation (Morris et al., 2005), change the economics of an industry (Magretta, 2002) and even make competition irrelevant (Kim and Mauborgne, 2004). Hence it may take a company in an entirely new competitive direction or introduce radical changes in established business paradigms (Christiansen, 1997; Nadler et al., 1997). Given this description, the business model innovation process comes with a "bundle of inherent perplexities and difficulties" (Najmaei, 2012). Therefore, the logic and dynamism of business model innovation necessitates a specific set of management skills (Demil and Leqocq, 2010) and various capabilities (Najmaei, 2012). Research on the business model innovation process, however, has not considered the apparent multifaceted structure of business models and what this actually implies for the innovation process.

To fill this research gap, we analysed the nature of business model innovation and its consequences for individual industry players in the Danish newspaper industry. A wide range of online news sources, together with a decline in readership and advertising and classified revenues, has put the newspaper industry in developed media markets under increasing pressure (Van der Wurff, 2005). The economic crisis has amplified this downward trend, with the above structural factors being compounded by cyclical factors (OECD, 2010). In response 
to these challenges, many media houses took a hard look at their value propositions and started using new Internet technologies, e.g. launching websites or designing apps for smart phones and tablets (Trench and Quinn, 2003).

Despite the success of these efforts in attracting increasing numbers of online users, newspapers have been unable to stop the downward spiral and generate enough income (Chyi and Sylvie, 2000). They have found it difficult to adapt the old business model to new circumstances, i.e. harness new technologies to monetize content, which in turn has led to a loss of market share and advertising revenue (PriceWaterhouseCoopers, 2009).

The aim of this paper is to identify the different approaches to business model change with regard to the main business model parts. To do so, we discuss how changes introduced during the ongoing development of digital platforms have affected the dominant business logic of three leading Danish newspapers and various elements of their core business model. In order to gain an in-depth understanding, we first carried out a review of literature in the field, subsequently identifying and collecting relevant industry reports. We also participated in relevant industry fairs and events, recorded professional presentations, as well as filed newsletters and press releases of professional newspaper organisations and associations for the years 2000 to 2012. Furthermore, we focused our efforts on two of the largest media groups in Denmark, carrying out twelve in-depth, semi-structured interviews with their top managers, e.g. CEOs, editors-in-chief, directors, etc. From these two media groups, three leading Danish newspaper titles with the highest circulation numbers were chosen for this investigation.

The paper contributes to the business model innovation literature by providing an in-depth insight into the business model innovation process, on which there is currently only little data available. Moreover, by outlining different innovation approaches, our research derives 
implications for the emerging stream of learning literature, which provides an important theoretical basis for conceptualizing the dynamics of the business model concept.

The paper is structured as follows. The next section presents an introduction to business model and business model innovation literature. This is proceeded with a brief overview of current developments in the newspaper industry and how major newspapers perceive and handle the move from printed to digital news publication. Following this a description of the qualitative research design, data collection and analysis is given and then key findings are presented and their implications are discussed and addressed.

\section{CONCEPTUAL BACKGROUND}

\subsection{BUSINESS MODEL}

The term business model became popular as a means to explain how an organization works during the rise of Internet and electronic businesses in the late 1990s. Its roots however can be traced as far back as Drucker's (1954) question of who the customer is, what does he value and how does a firm expect to earn money (Magretta, 2002)? Despite the popularity of the term, both in research and practice, no uniform definition or taxonomy exists (see Morris et al., 2005; George and Bock, 2011; Zott et al., 2001 for summaries of the existing business model literature). This lack of consensus may in part be attributed to the wide range of disciplines that show interest in the concept, all of which have arrived at a different - mostly industry-specific - understanding (e.g. Rajala \& Westerlund, 2007). Accordingly, this heterogeneous background has led to today's business model research being comprised of many facets.

Regardless of the diversity of current contributions and understandings, researchers and practitioners agree that all companies have a business model, whether they articulate it or not, 
and that at its core, a business model describing the value proposition performs three important functions: value creation, value capture and value delivery. It is the analysis of these core elements that is crucial to the research being undertaken in this paper. Although it is not always clear why a specific business model is successful or not, it is generally agreed that a well-functioning business model is essential for the success of any commercial organisation, whether it be a new venture or an established company (Magretta, 2002).

As a conceptual tool, a business model explicitly states how a business functions. It serves as a blueprint for systems that constitute the company's operational and physical form (Nadler et al., 1997). A business model describes the value a company offers to one or several (segments of) customers and consumers, and the architecture of the internal processes of the firm and its networks of partners in creating, marketing and delivering value in order to generate profitable and suitable revenue streams. Thus, a business model helps to capture, visualize, understand, communicate and share business logic (Nadler et al., 1997; Osterwalder et al., 2005).

An accepted business model approach in research and practice is the Business Model Canvas introduced by Osterwalder and Pigneur (Fritscher and Pigneur, 2010; Osterwalder and Pigneur, 2010). Their business model, which can be described as a set of nine interrelated building blocks, is shown in Figure 1. The nine building blocks are:

1. The value proposition of the product offered to the market;

2. The segment(s) of clients addressed by the value proposition;

3. The communication and distribution channels used to reach clients and offer them the value proposition;

4. The relationships established with clients; 
5. The revenue streams generated by the business model (constituting the revenue model);

6. The key resources needed to make the business model possible;

7. The key activities necessary to implement the business model;

8. The key partners and their motivations for participating in the business model; and

9. The cost structure resulting from the business model.

Figure 1. The nine building blocks of the business model

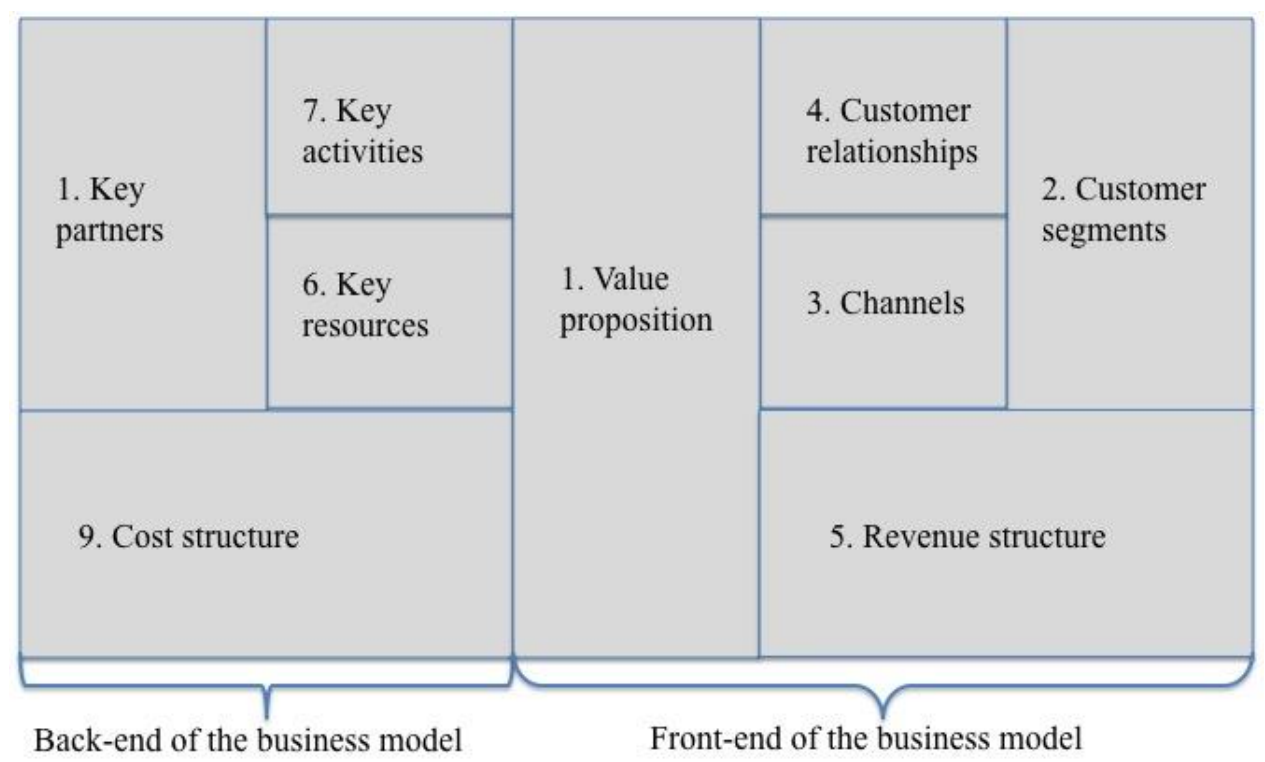

Source: Adapted from Osterwalder and Pigneur (2010)

Elements two to four constitute the value delivery elements, six to eight the value creating elements, while elements five and nine are related to value capture of a business model. More broadly speaking, these nine elements can be divided into two main categories - the front-end and the back-end of the business model. The front-end (right side of the canvas) emphasizes value, while the back-end (left side of the canvas) is predominantly efficiency driven (Osterwalder and Pigneur, 2010:p.49). This multifaceted structure of the business model may give rise to a "bundle of inherent perplexities and complexities" in the business model innovation process (Najmaei, 2011). 


\subsection{BUSINESS MODEL INNOVATION}

The importance of business model innovation has increased in recent years, since companies no longer regard product innovation as the only source of competitive advantage. The glut of market choice in products and services means that often innovative business models are what differentiate global competitors (Amit and Zott, 2012).

But there is more to it than that: business model innovation is relevant for both start-ups trying to attain significant size and profitability (e.g. Zott and Amit, 2007) and incumbents trying to adapt to change or seize opportunities outside their core operating space (e.g. Johnson, 2010). Business model innovation is important because it is a form of innovation in itself; it can complement other forms of innovation, and it is often required to commercialize new technologies (Amit and Zott, 2001). Radical business model innovations have the potential to shake whole industries (Demil and Lecocq, 2010; Steenkamp and van der Walt, 2004), and can result in a competitive advantage if they are hard to replicate (Magretta, 2002).

Chesbrough (2010) analyzed two main types of barriers for business model innovation in organizations. One results from inability of the firm to adjust existing resources to complex change, and the other from the constraining effect of the current business model upon potential new ideas. The dominant logic trap and the identity trap (Tripas and Gavetti, 2000) are similar phenomena, and according to different authors experimentation is the key to finding suitable business models, pointing to the need for hypotheses, tests and revisions (Magretta, 2002; Chesbrough, 2010; McGrath, 2010). In a similar vein, other authors emphasize the importance of trial-and-error learning during the process of business model innovation (Santos et al., 2010). Trial-and-error learning and/or experimentation are nonlinear, non-orderly, non-predictable processes and are proposed by literature to be applied in situations of great uncertainty (e.g. Thomke et al., 1998). 
Research into the process of business model innovation could shed more light on the phenomena, but patterns observed vary significantly. This is perhaps best depicted by two extremes in the literature: organic flexibility and structured rigidity. Organic flexibility refers to a business model innovation process that is messy and cannot be captured in structured steps, where the business model is continuously evolving and based on a design attitude (Sosna et al. 2010; Osterwalder and Pigneur, 2010; Bolland and Collopy, 2004). In contrast, structured rigidity can be described as a controlled process in which previously determined results are used in the following phases, with the focus on implementing a new business model step-by-step (Elbers, 2010; Pateli and Giaglis, 2004).

It is noticeable that none of the current contributions take into consideration either the level of uncertainty an incumbent is faced with, or the multifaceted structure of business models. This paper wants to investigate the influence of the latter on the business model innovation process, as it is proposed that the current 'one-size fits all' approach is rather surprisingly not taking the differences between the core business model elements into account.

New product development literature may shed some light on diverse approaches for frontand back-end innovation. Sperry and Jetter (2009) propose that a front-end innovation process requires room for iterations, while a back-end innovation process might be better defined and thus processes can be linear. The authors depict five different processes that can be applied:

1) Linear - deterministic and bottom-up;

2) Recursive - multiple feedback loops that produce an iterative and integrative type of behavior;

3) Evolving - feedback learning for the purpose of exploiting and refining direction;

4) Selectionism - multiple independent concepts for testing to pick the best; and 
5) Trial-and-error/experimentation - non-linear approach to ensure exploration and exploitation.

The trial-and-error process deals with unforeseeable uncertainty and complexity through exploratory learning and is more suited for radical or breakthrough changes. Although recursive, evolving and selectionism are different processes, they all incorporate the principal of concept testing and rely upon exogenous (e.g. customer preferences or needs) or endogenous (e.g. new accounting system) feedback. It can be argued that these three processes do not deal as well with uncertainty as the trial-and-error process and thus are better suited for incremental improvements rather than disruptive changes. Finally, linear processes tend to encourage management processes that empathize strategic alignment, profitability and market awareness, and are thus suited for incremental improvements and medium to low levels of uncertainty.

So far, there has been very limited data on the process of business model innovation when emerging technologies disrupt mature industries. Additionally, current literature has not taken into account the multifaceted structure of the business model. This paper aims to contribute to the business model innovation literature by presenting and discussing data from a study of the newspaper industry in Denmark.

\section{THE CURRENT DECLINE OF THE NEWSPAPER INDUSTRY}

\subsection{THE TRADITIONAL NEWSPAPER BUSINESS MODEL}

Newspapers were the intermediaries between the world and its citizens. The traditional business model of the newspaper industry was characterized by the ability of newspapers to control the entire value chain of news reporting and dissemination. This model gave economic equilibrium and independence to newspapers for many years. Moreover, like many 
markets with network externalities, the newspaper industry had two distinct sides, whose ultimate benefit stemmed from interacting through a common platform - the newspaper itself. In short, the reader (loss leader) attracts advertisers (profit centre), cross-subsidising the production of news through the sale of advertising. Such business models are called multisided business models (Osterwalder and Pigneur, 2010), as the interaction between the two sides gives rise to strong complementarities.

Traditionally, newspapers all over the world have had a high profit margin, deriving about 57\% of their revenues from advertising and about $43 \%$ from newspaper sales (OECD, 2010). For media houses in mature media markets, the situation changed dramatically in the first decade of the $21^{\text {st }}$ century, when the industry came under pressure from declining sales of advertising space and subscription revenues. According to OECD (2010) between 2004 and 2009, about 20 out of 30 OECD countries faced declining newspaper readership, which, led to a decline in readership in the United States (34\%), in the United Kingdom (22\%) and in Japan (18\%).

This same was true for the Danish newspaper market, where overall newspaper circulation declined rapidly during the first decade of the 2000s, from 1,600,000 in 2000 to $1,130,000$ in 2010 (free newspapers not included). The fall in newspaper circulation can be attributed to many changes in the media landscape, but mostly the downturn is blamed on the Internet (The Economist, 2006; The Economist, 2011).

\subsection{THE IMPACT OF THE INTERNET ON THE NEWSPAPER INDUSTRY}

The Internet has changed the newspaper market in diverse and complex ways - taking the industry back to an emergent stage. First as the presence of the Internet grew, the newspaper industry quickly fulfilled the desire of its readers to access news online, resulting in worldwide online newspapers and other online news media growing significantly during the last half of the 1990s (OECD, 2010). At the time practically all major newspaper titles 
launched websites and started to publish their content online. For example, Le Monde (France) set up its website in 1995, followed by the New York Times (USA) and later by the Danish national daily Jyllands Posten (JP) in 1996. Second, new media players with global coverage and seemingly 'unlimited' resources entered the media market, taking advantage of the free online content of traditional newspapers. This created a new type of rivalry in markets that had previously been local, pulling readers and advertisers away from traditional newspapers. Twenty years ago other newspapers were the major competition, now however, the most dangerous competitors are the news aggregators, such as Google, Yahoo and Microsoft, and the popular social media sites, such as Facebook. Moreover, device or network service providers who did not play any role in the traditional model suddenly began to control access to the end consumer and have a large degree of bargaining power with content providers. As such, newspapers had to enter strategic partnerships and revenue sharing models with a new set of very important actors. In this new online ecosystem, users themselves were increasingly becoming diffusers, commentators and creators of news. Readers involved in news creation and diffusion included those commenting on news through blogs, contributing to news via relevant citizen journalism platforms, rating or sharing news on social networks, or submitting photographs, videos or stories.

In this new context, the production and dissemination of news is a much more interactive and multi-directional affair, rather than a linear process, which calls for new skills and technologies. On top of this complexity, innovative Internet-based solutions provided by online (non-newspaper) companies facilitated the move of most consumer-to-consumer classified advertising to the Internet - a development initially overlooked by newspaper organisations (Mings and White, 2000).

In such a situation, both incumbents, i.e. existing newspapers, and new entrants, i.e. borndigital news media, compete to identify the industry's most strategically valuable 
competencies (Gambardella and McGahan, 2010) and the value propositions which will serve customers best (Agarwal and Bayus, 2002), and then change their business models accordingly. The focus of our analysis is the business model innovation in the existing newspapers, i.e. incumbent firms.

\section{RESEARCH DESIGN}

The aim of this study is to enhance the understanding of the business model innovation process in incumbent firms faced with a disruptive technology by establishing a basic understanding of the context-specific phenomenon and providing insights into future research areas. According to Yin (2002) and Flyvbjerg (2006), key factors that underlie a proposed study, such as the complexity of the research topic, the nature of the study, the type of research question(s) and research purpose, suggest the use of a qualitative methodological approach. They argue that interpretive methods like, multiple case studies, are the preferred method to study complex social phenomenon deeply embedded within a real-life context (George and Bennett, 2005; Hancock and Algozzine, 2006; Stake, 2005; Yin, 2009). Qualitative data was considered to be appropriate, since it can provide meaningful, novel insights into complex social processes (Eisenhardt and Graebner, 2007), like ongoing business model change and innovation.

\subsection{SAMPLING}

The point of convergence we have chosen is the Danish newspaper market, since this gives us the opportunity to observe in detail JP/Politikens Hus and Berlingske Media, the two largest privately-owned newspaper publishers in Denmark. At the time of research, JP/Politikens Hus and Berlingske Media owned a vast portfolio of media, varying from traditional daily newspapers to radio stations and web-TV channels. These two groups own the three leading national daily titles - Berlingske (Berlingske Media), Jyllands-Posten and Politiken (JP / 
Politikens Hus) (for an overview see table 1), and so control $50 \%$ of the national newspaper market $(80 \%$ of the nationally distributed newspapers according to The Nordic Media Market Report, 2009). These newspapers were chosen for the study, since all three are largely sold on a subscription basis and have a high national outreach within Denmark. On the other hand, the three newspapers are organized and managed differently and have different foci, thus adding variance to our sample and creating the opportunity to gain additional insights in how organizational structure might affect the ability to innovate.

Table 1. Newspapers in the study as per end of 2011

\begin{tabular}{|c|c|c|c|}
\hline & Berlingske & Jyllands-Posten & Politiken \\
\hline Established & 1749 & 1871 & 1884 \\
\hline Positioning & $\begin{array}{l}\text { Denmark's "liberal" } \\
\text { newspaper }\end{array}$ & $\begin{array}{l}\text { Denmark's } \\
\text { “international "newspaper }\end{array}$ & $\begin{array}{l}\text { Denmark's "spirited" } \\
\text { newspaper }\end{array}$ \\
\hline Outreach & $\begin{array}{l}\text { Readers weekdays: } \\
270,000 \\
\text { Readers Sundays: } \\
384,000 \\
\text { Real users online: } \\
520,998 \text { (6/2011) } \\
\text { Visits online: } \\
4,769,004 \text { (6/2011) } \\
\text { Visits mobile: N/A }\end{array}$ & $\begin{array}{l}\text { Readers weekdays: } 389,000 \\
\text { Readers Sundays: } 513,000 \\
\text { Real users online: } 716,000 \\
\text { (6/2011) } \\
\text { Visits online: } 10,427,672 \\
\text { (6/2011) } \\
\text { Visits mobile: } 602,178 \\
(6 / 2011)\end{array}$ & $\begin{array}{l}\text { Readers weekdays: } \\
368,000 \\
\text { Readers Sundays: } 467,000 \\
\text { Real users online: } 786,718 \\
\text { (6/2011) } \\
\text { Visits online: } 10,395,516 \\
\text { (6/2011) } \\
\text { Visits mobile: } 592,714 \\
(6 / 2011)\end{array}$ \\
\hline $\begin{array}{l}\text { Revenue } \\
\text { structure }\end{array}$ & $\begin{array}{l}90 \% \text { of the } \\
\text { newspaper's } \\
\text { circulation is sold to } \\
\text { subscribers. } 50 \% \text { of } \\
\text { the paper's revenue } \\
\text { is from the sale of } \\
\text { advertisements }\end{array}$ & $\begin{array}{l}90 \% \text { of the newspaper's } \\
\text { circulation is sold to } \\
\text { subscribers. } \\
\text { Some } 40 \% \text { of the paper's } \\
\text { revenue is from the sale of } \\
\text { advertisements }\end{array}$ & $\begin{array}{l}93 \% \text { of the newspaper's } \\
\text { circulation is sold to } \\
\text { subscribers. } \\
\text { Some } 30 \% \text { of the } \\
\text { newspaper's revenue is } \\
\text { from the sale of } \\
\text { advertisements }\end{array}$ \\
\hline $\begin{array}{l}\text { Number of full- } \\
\text { time employees }\end{array}$ & N/A & 500 & 400 \\
\hline \multirow[t]{2}{*}{ Going online } & 1998 & 1996 & 1998 \\
\hline & Main site - b.dk & Main site - jp.dk & Main site - politiken.dk \\
\hline
\end{tabular}




\subsection{DATA}

In order to acquire a more thorough knowledge of the newspaper industry and its dynamics, we started our research by reviewing existing academic and professional literature related to media and newspaper management. We then analysed a number of international industry reports, and attended Danish and international professional media events, conferences and workshops. Subsequently, we shifted our focus to the newspaper industry in Denmark, looking at Danish Newspaper Association newsletters covering the period 2002-2011, which dealt with ongoing developments in the Danish mass-media sector. We also collected publicly available archival information on the two media groups and their newspapers in the study. Then to gain first-hand insights of newspaper executives, we developed an interview guide and conducted four in-depth, face-to-face, semi-structured interviews with key informants from each newspaper. These included a CEO, two editors-in-chief, two directors, a head of product development, a CIO, a sales director, two heads of business development, a director for digital products and a chief of a regional edition. (To protect the anonymity of our respondents, we do not specify which newspaper they represent). All face-to-face interviews with the informants were conducted onsite, digitally recorded, and subsequently fully transcribed. Each interview lasted between $1 / 2$ to $1 \frac{1}{2}$ hours.

The data sources included in the data analysis are summarised in Table 2.

Table 2. Data sources

\begin{tabular}{|c|c|c|c|}
\hline Data type & Sources & Data format & Length \\
\hline $\begin{array}{l}\text { In-depth, face- } \\
\text { to-face, semi- } \\
\text { structured } \\
\text { interviews }\end{array}$ & $\begin{array}{l}\text { Key informants, e.g. } \\
\text { managers, executives and } \\
\text { editors-in-chief }\end{array}$ & $\begin{array}{l}\text { Digital sound } \\
\text { recordings and } \\
\text { transcriptions }\end{array}$ & $\begin{array}{l}12 \text { recorded } \\
\text { interviews of } \\
\text { approx. } 99,600 \\
\text { words }\end{array}$ \\
\hline
\end{tabular}




\begin{tabular}{|c|c|c|c|}
\hline Data type & Sources & Data format & Length \\
\hline $\begin{array}{l}\text { Professional } \\
\text { presentations }\end{array}$ & $\begin{array}{l}\text { International media } \\
\text { industry executives, i.e. } \\
\text { editors, development } \\
\text { directors, holding directors, } \\
\text { CEOs, vice-presidents, etc. }\end{array}$ & $\begin{array}{l}\text { Recorded sound files } \\
\text { and copies of } \\
\text { presentations }\end{array}$ & $\begin{array}{l}\text { Approx. } 14 \text { hrs. of } \\
\text { recordings and } 22 \\
\text { presentation files }\end{array}$ \\
\hline \multirow[t]{2}{*}{ Archival data } & $\begin{array}{l}\text { Newsletters of the Danish } \\
\text { Newspaper Association } \\
(2000-2011)\end{array}$ & Text copies & $\begin{array}{l}409 \text { documents of } \\
\text { approx. 593,740 } \\
\text { words }\end{array}$ \\
\hline & $\begin{array}{l}\text { Annual reports of } \\
\text { Berlingske Media, } \\
\text { MECOM, JP / Politikens } \\
\text { Hus, and their Danish } \\
\text { newspaper titles }\end{array}$ & $\begin{array}{l}\text { Brochures and } \\
\text { electronic files }\end{array}$ & $\begin{array}{l}20 \text { documents of } \\
\text { approx. } 427,000 \\
\text { words }\end{array}$ \\
\hline
\end{tabular}

\subsection{DATA ANALYSIS}

We applied a data-driven approach to data analysis (Gibbs, 2007:45) within the business model research framework as defined earlier in the literature review part of the paper. The fully transcribed interviews, newsletters, audio recordings and presentations relevant to the study were exported to QSR nVivo 9 software. The coding started with data reduction (Miles and Huberman, 1994:10-11), where only data with direct relevance to the three selected newspapers in the study were selected. We then reduced the data further to the building blocks of the business model framework.

We then proceeded with open coding (Strauss, 1987; Corbin and Strauss, 2008) of the interviews and applied analytic coding (Gibbs, 2007:44), looking for changes to the business model, i.e. consequences (Strauss, 1987: 28-32) due to the disruptive technologies. Codes were introduced inductively to represent specific characteristics of business model innovation and experimentation activities, e.g. "free digital content", "mobile platform delivery", "smart phone apps", “e-commerce", “experimentation", "new customer segments", etc. The emerging codes were modified iteratively throughout the analysis (Eisenhardt, 1989). The coded data segments were then grouped and organised into topics and categories were refined 
(Patton, 2002:454; Creswell, 2009:186). To overcome problems of bias and validity (Blaikie, 1991) - and to capture a more complete, holistic, and contextual portrayal of the cases (Jick, 1984:365) - we then applied data triangulation (Denzin, 1978), combining data from the interviews with archival, secondary and professional presentation data (Patton, 2002).

Finally, we analysed the relationships between different parts of the business model before and after the introduction of digital content and news delivery solutions to the newspapers' product portfolios. A cross-case analysis and separate results presentation proved not to be useful, since an initial comparison showed that the three newspapers had developed quite similarly.

\section{FINDINGS}

Generally, both media houses were very open to technological and social innovation, like the World Wide Web, Web 2.0 and the various mobile platforms, Apple's iOS, Google's Android, etc. Jyllands-Posten was one of the first Danish newspapers to launch an online edition, www.jp.dk, in early 1996. Berlingske and Politiken followed suit soon after, publishing online editions in 1998.

The following section summarizes how the three Danish newspapers approached technological and social innovation with regard to the major building blocks of the business model - value proposition, value creation, value delivery and value capture, and shows how they proceeded with business model innovation in various ways - from linear to experimental (please see appendix 1 for a detailed overview of all changes regarding all building blocks).

\subsubsection{VALUE PROPOSITION}

In the beginning of the Internet era, newspapers did not find it necessary to change their main two-sided platform value proposition, i.e. the printed newspaper, which connected readers 
and advertisers. When it became evident that this long-standing value proposition did not hold, newspaper managers blamed themselves for devaluing content in the readers' minds by making news freely available on the Internet. As one of our respondents put it:

"This was our biggest mistake - we gradually transferred more and more of our journalism [to the Internet]. In the beginning, it was just news, then it was columns and blogs. We have more or less transferred all of our professional content, and it is only connoisseurs of journalism who can see the difference because we call everything news."

Respondent from Berlingske (our translation)

As Teece (2010) points out, every new market offering effort should be coupled with the development of a business model that defines its marketing and value capture strategies. In this sense, newspapers made the same mistake as many technology companies before them they assumed that (adaptation to) technological innovation would automatically guarantee financial success.

After the newspapers realized that they could not rely solely on being a unique news channel, connecting advertisers, marketers and readers, all three newspapers in the study tried to renew their value proposition. Nonetheless, all three newspapers set great store in being a credible news channel for readers, as the following interviewee puts it:

"Well, we should be the credibility channel verifying things. People always search for channels where they believe to hear the truth. Maybe there is a super blogger with the right contacts in the government or wherever - and therefore people will perhaps turn to him when it concerns his main subject field. But in such cases, it is clearly easier to be a media firm or a media with tools to get things verified."

Respondent from Berlingske (our translation) 
What the above illustrates, the newspapers adapt their value proposition of being the "credibility channel" to the new Internet domain, where this credo might be of even more importance. Additionally, news customization - choosing the most important news - is also of increasing value. This is still at an early stage of development, but the analysed newspapers are clearly aware that this could be a new value proposition and thus a tool to differentiate them from competitors.

To develop the value proposition of the newspaper further, the interviewee suggests that the newspaper take on a new role - that of entertaining.

"There is much verification, but, I still believe that we have a huge role in entertaining, informing and collecting."

\section{Respondent from Berlingske (our translation)}

All the newspapers have started focusing on maintaining and building their strong brands, presuming that, in current market conditions, the medium is secondary to the brand. One of the interviewees from Jyllands-Posten puts it as follows:

"We live for our brand. We want to be a media house with a common denominator our brand. And we are doing it at full speed. I mean, we are on the radio and online, and we are working in so many different ways. What we say is actually that our asset is our brand, and that it is omnipresent in all our activities." (our translation).

However, the strong position of the brand and the newspapers' own brand awareness seems to make them hesitant when it comes to creating new value propositions and thus fulfilling new customer needs. This is well illustrated in the following quote.

"It is quite clear that there is a major challenge in becoming sharper in our offer. [...] Let's say, you could buy a [tailored] package [instead of a standard newspaper]. [...]. 
But it's a difficult balance, because I think our brand is invaluable to us. So the moment you begin to atomize your content, you also risk undermining your brand, so the balance is very, very fragile here."

Respondent from Jyllands-Posten (our translation)

The newspapers in this study have only slowly changed their value proposition and this can best be depicted as an emerging process. The innovation process of the value proposition is influenced by the customer, insights from the market as well as by a company's own values and structures. It is a learning-feedback process with multiple iterations. The process is not unstructured, but is rather a process that is constantly refined with one iteration building up from another. Using the presented typology from the new product development (see section 2.3), this approach is best represented by the evolving innovation process.

\subsubsection{VALUE DELIVERY}

All the newspapers in the study have grasped new opportunities within the merged media space by strongly focusing on building their brand on multiple platforms, thereby offering people access to newspaper content through various channels. Interviewed newspaper managers were convinced that the future of the newspaper industry lies in delivering customer value through preferred multiple media platforms and channels. The newspapers have also recognised the role that other digital media channels play in distributing their content and redirecting readers to newspaper websites. For example, in 2010, Berlingske started publishing articles suitable for this purpose from berlingske.dk on Berlingske's Facebook page, designating community managers to keep an eye on the debate and the initiatives in progress and to respond to the users' questions. In the same year, Berlingske launched GoNews, a news channel on the Microsoft-owned MSN.com. This move allowed the newspaper to deliver content to 1.3 million Danish users of MSN.com. In July 2011, 
Jyllands-Posten and Berlingske joined forces with Denmark's largest cable TV provider, TDC, to deliver news on TV. This joint initiative enabled 120,000 cable subscribers to access jp.dk and b.dk newspaper sites via their television sets. TDC called the news service TV apps, and considers it to be a modern version of Teletext, with news, weather, music, etc. The service is easily accessed using the remote control via applications at the bottom of the TV screen, and is available for TDC Internet TV subscribers. While there was little doubt that newspapers had to be on such digital platforms, others, like Facebook and Twitter, encouraged greater experimentation by the newspapers:

\footnotetext{
"Social media $[\ldots]$ Yes, we are trying so $[\ldots]$ we have not found the model making sense for us, but we are there, [...] and we have occasionally used it editorially. And it's actually Twitter we have used in regard to some trials we have followed with regular updates, and it was a great challenge, but also an editorial success, and our hard-core users also thought that it was really good. But otherwise, we should probably think a little more about how we use it. What we would like to get out of it is to get more customers, and more loyal customers, but so far we have not found a suitable model for this."
}

Respondent from Berlingske (our translation)

The newspapers still aim to satisfy advertisers and marketers, and have recognised the need to take a harder look at their cross-platform print and online offerings. Newspaper publishers have therefore started experimenting with digital channels in order to serve their advertisers more effectively. This includes Internet activities, web-TV, mobile, social media sites, etc.

To deliver value to their customers, the newspapers in this study have chosen a trial-and-error approach. In a non-linear and non-orderly way, these newspapers have defined and tested multiple independent alternative approaches to value delivery. Thus they have gained 
knowledge about customer profiles, customer usage of various platforms and channels, advertiser preferences, etc. This information has been used to understand current trends and customer behaviour and thus tells the company how they can reach out to various groups of readers and advertisers.

\subsubsection{VALUE CAPTURE}

Being present on all new media platforms has meant that the newspapers quickly attracted large numbers of unique visitors to their websites and therefore increased the overall readership, however, it did not bring about the revenues that the newspapers had hoped for. Furthermore, switching to various Internet editions for quick news encouraged some readers to abandon printed editions - leading to a significant decrease in revenue.

After several years without mainstream payment from the Internet, newspapers woke up and realised that it this model was no long-term solution. Users' willingness-to-pay was not easy to evaluate, so newspapers started experimenting with various new revenue models and online payment systems, e.g.:

"But what we can do is to make smaller experiments with payment - for example, our iPhone app that we've developed - and use this in an attempt to find out what users are willing to pay for. And we've launched it with a monthly payment of $€ 1.60$ to test the willingness-to-pay among our users. It is only a small experiment, but it is a very good indicator of what loyal customers, who are interested in the Politiken brand, think of paying once a month."

Respondent from Politiken (our translation)

As the newspapers looked for ways to reverse decreasing revenues, other sources of revenue, like e-commerce, became increasingly important, since it allowed them to capitalize on their 
brands reputation and huge Internet traffic to their online sites. In 2004, Politiken launched the e-commerce site plus.politiken.dk, which offers specially selected goods and services. This shop actually started "offline" in Copenhagen in 1978. Until recently, the shop was just an add-on, but a very consistent marketing approach has brought growing revenues (3\% of the total revenue of the media house) and resulted in the opening of a second "offline" shop in Copenhagen. Berlingske also operates a number of e-commerce websites with special offerings, which have mostly no connection with the newspaper's core business activities, such as the e-commerce site Sweetdeals.dk by Berlingske Media.

"We have Sweetdeals and everything else, which you could say is non-traditional revenue - we also have commercial sales, everything from firewood to travels. So, the more we can earn here to fund our core business of journalism and content, the better. And if we can couple it, it is even better. So there are lots of different ways to get revenues in."

Respondent from Berlingske (our translation)

All newspapers were thus experimenting with alternative sources of revenues and collecting additional customer data. However, since they still maintain their traditional business model from the printed newspaper age, they also need to manage the co-existence of print, online and mobile business models.

To investigate new value capture mechanisms, the newspapers in this study have chosen a selectionism approach, defining multiple independent alternative payment approaches and testing them rigorously. After testing, they pick the most successful, implement and scale them. 


\subsubsection{VALUE CREATION}

Changes in technology and competition have forced the newspapers to reassess the qualifications of in-house personnel. One result is that they have identified a growing need for journalists with digital skills.

"We have hired four employees with specific digital skills, because our existing employees could not manage the tasks themselves. People tried, but did not have the right skills - for blogging live or embedding, using Google maps in articles and web TV clips and mixing dissemination forms easily online. We soon realised that we had to specifically search for employees who already had the skills."

Respondent from Berlingske (our translation)

"We need people who can develop the journalistic products. Content development now goes in tandem with technological development. So we will look just as often for IT people or those with a background in digital media studies, because they have a slightly broader perspective on product development and innovation [than traditional journalists]."

Respondent from Jyllands-Posten (our translation)

In addition, newspapers from both media groups have established a number of partnerships in completely new areas, e.g. an advertising agreement between JP/Politikens Hus and eBay, or Berlingske Media's development of mobile solutions with a Ukrainian IT firm. According to one of the representatives from this media group, there is a fairly strong development in this field, with collaborations increasingly reflecting two main directions: "digital development and a high degree of internationalisation". Many newspapers have also outsourced printing and distribution, which makes them even more dependent on outside companies. 
Additionally, faced with falling revenues and a shrinking readership base, newspapers have re-evaluated their market offerings and cut costs where possible. This included eliminating badly performing products and arrangements.

"As far as our printed newspapers are concerned, we have had a falling circulation for at least 10 years. It's partly a controlled fall - we've eliminated a number of subscription plans which were unprofitable for us."

Respondent from Berlingske (our translation)

Changes to value creation correspond to the changes in the other three parts of the business model. Therefore, these changes are well planned and controlled and of a linear nature. Key resources and key partners are employed, key activities are implemented and costs are optimized to enable and "back-up" the delivery of a renewed value proposition from which the company can capture value.

\section{Discussion \& CONCLUSION}

Our research shows that newspaper industry players recognise the need to reconsider the extent to which their existing businesses are efficient, effective as well as customer-centric, and to examine which strategy to adopt to cope with the challenges of the $21^{\text {st }}$ century.

However, our research also suggests that following a technological innovation trend and adjusting business models accordingly is an enduring task - adopting a new technology seems 'uncomplicated' compared to adapting a new business model - especially for incumbents with a long-standing history. These observations have implications for both practice and research.

Until now research suggested that business model innovation is a chaotic process - pointing towards experimentation and trial-and-error learning approaches (Magretta, 2002; Sosna et al. 
2010). Our paper sheds a more differentiated view on the business model innovation process. Thereby, we find that experimentation and trial-and-error learning can be part of business model innovation, but that it does not apply to the business model as a whole. Rather for front-end innovation these approaches seem suitable while for back-end innovation more linear approaches are adequate. Aggregating these approaches we argue for a so-called structured flexibility approach as proposed by Biazoo (2009) in the field of new product development. Trial-and-error, selectionism and evolution in the front-end of the business model are coupled with a linear approach in the back-end. Through the implementation of multiple innovation approaches the business model can be a strategic tool for capturing purposefully value from firms' front-end innovations (Chesbrough and Rosenbloom, 2002).

From another point of view one could argue that the newspapers have changed - but unsystematically from the perspective of the whole business model. Although the newspapers studied have continuously innovated business model elements, the question of how innovation approaches can go hand in hand, inform each other and build on each other arises, and we did not find evidence in our data that these approaches were coordinated. Clearly, separate business model innovation processes can even be harmful, if they are not linked to other efforts, since this can disrupt the business model logic. Many changes in the business model business blocks presented in Annex 1, were of a disruptive nature to the dominant business model, and undermined the value capture flow as they were not coupled with other innovation process outcomes. This observation strongly favours a coordination of the different business model innovation processes. The process of business model innovation always needs to be related to the business model logic to ensure the value of each innovation step.

The multifaceted structure of business model innovation requires its own set of resources and capabilities. This calls for a purposeful inter and intra organizational process of strategic goal 
development and dissemination conducted by top level management. The dynamic management of relational capabilities, as well as individual and organizational learning becomes a cornerstone to successfully managing and developing the business model.

\subsection{IMPLICATIONS FOR PRACTICE}

As the term business model becomes appealing to practice and academia, and business model innovation is recognized as a novel innovation paradigm to achieve competitive advantage, it becomes increasingly apparent to understand the multifaceted structure of both the business model and the business model innovation process. Managers should consider sharing knowledge about different innovation approaches in their organizations - emphasizing that these cannot only be applied for product but also for business model development. It could be valuable for organizations to engage in knowledge sharing on cross-functional experiences about innovation approaches.

It became apparent in our study that innovation and change to the value proposition is the most enduring task for an incumbent - resonating with previous findings on the dominant logic and the identity trap (Tripas and Gavetti, 2000). Ouden (2012) presents a practical four level value framework which might give inspiration to managers on how to approach redefining the value proposition from an integrative thinking perspective.

The rapid spread and adoption of online and mobile technological platforms have created new opportunities for newspaper publishers. However, transferring an existing product (newspaper) from the analogue platform (paper-based) to the digital (Internet-based) does not automatically guarantee increased and/or sustained sales. For this to happen, more value needs to be added to the product. Moreover, if the key value to the buyer (and subscriber) is news, and that this part of the digital version of the newspaper is offered free, then revenues must come from additional sources and/or services. The challenge and complexity of the 
markets imply that, to stay afloat and generate profit for digital products, newspaper publishers must have a mix of revenue models (Mings and White 2000). A trial-and-error approach is an insightful way to generate knowledge on customer groups and revenue stream alternatives. Companies should ensure that access to the gained knowledge is given across the company, as this information might also be of interest to other divisions. Thus, individual and organizational learning become cornerstones of successful business model innovation.

\subsection{IMPLICATIONS FOR RESEARCH}

Our research is subject to several limitations. First of all, we focused on the Danish newspaper industry, which has its own particularities, and where there may also be a location and industry bias. Second, as a framework for analysis, the chosen business model ontology (Fritscher and Pigneur, 2010; Osterwalder and Pigneur, 2010) limits the research to the nine building blocks. Using another research frame might have widened the focus to other business model areas. Nevertheless, we felt that working with this business model ontology was easily translatable into practice (for the interviews) and research (for the coding), and therefore the most suitable approach.

Our study resulted in a number of insights, but also raised some open questions. The usefulness of longitudinal studies of mature ventures for research on business model development became apparent. Media owners have been strongly encouraged to develop consumer-centric strategies and to keep innovating in order to identify advantageous opportunities for accommodating the interests of readers and advertisers (McPhillips and Merlo, 2008). This includes the ways in which firms interact with suppliers as well as customers (Brynjolfsson and Hitt, 2000). Therefore, as suggested by Chyi and Sylvie (2000), longer studies of the strategic behaviour of online newspapers are needed if we want a more accurate idea of the predominant business models of the future. Additionally, longitudinal 
studies would give valuable information on organizational learning, which is an important theoretical basis of business model innovation and change.

The multifaceted structure of business models requires its own diversified leadership approach. We do not have a clear sense on how back-end and various front-end innovation approaches should be coordinated, raising a number of future research questions. Who should coordinate and initiate business model innovation processes? What kind of leadership style is needed to bridge its multifaceted structural components? What kind of company culture needs to be created to support various forms of innovation and change processes?

Another field for further investigation concerns whether the front-end and back-end innovation approaches should run sequentially or in parallel? Are certain business model elements to be innovated sequentially? How can knowledge sharing across functions and divisions be enabled if innovation processes run in parallel? Which costs arise through various innovation approaches and how can bundling and distributing knowledge be optimized? Product development literature (e.g. Thomke et al., 1998) provides insights into a number of trade-offs between innovating in a sequential vs. parallel fashion. This literature might be a good starting point for further investigations of this area.

Lastly, the role of legitimacy in business model innovation processes needs to be explored. Our interviewees reported that they feared experimenting with the value proposition, since they assumed that failure would lead to a decrease in the value of their brand. This indicates that managers miss tools and an understanding of innovation processes that can increase legitimacy. An investigation of stakeholder perception of various business model innovation approaches could potentially shed light on this issue. 


\section{REFERENCES}

Agarwal, R and BL Bayus (2002). The market evolution and sales takeoff of product innovations. Management Science, 48(8), 1024-1041.

Amit, R and C Zott (2001). Value creation in E-business. Strategic Management Journal, 22(6-7), 493-520.

Amit, R and C Zott (2012). Creating value through business model innovation. MIT Sloan Management Review, 53, 40-49.

Biazzo, S (2009). Flexibility, Structuring, and Simultaneity in New Product Development. Journal of Product Innovation Management, 26(3), 336-352.

Boland, RJ and F Collopy (2004). Managing as Designing. Stanford, Cal.: Standfort University Press.

Brynjolfsson, E and LM Hitt (2000). Beyond computation: Information technology, organizational transformation and business performance. Journal of Economic Perspectives, 14(4), 23-48.

Casadesus-Masanell, R and J. Tarziján (2012). When one business model isn't enough. Harvard Business Review, 90(1), 132-136.

Chesbrough, H (2010). Business Model Innovation: Opportunities and Barriers. Long Range Planning, 43 (2-3), 354-363.

Chesbrough, $\mathrm{H}$ and Rosenbloom, RS (2002). The role of the business model in capturing value from innovation: Evidence from Xerox Corporation's technology spin-off companies. Industrial and corporate change, 11, 529-555.

Chyi, HI and G Sylvie (2000). Online newspapers in the U.S: Perceptions of markets, products, revenue, and competition. International Journal on Media Management, 2(2), 69 - 77.

Christiansen, CM (1997). The Innovator's Dilemma. Boston, MA: Harvard Business School Press.

Clemons, EK (2009). Business models for monetizing internet applications and web sites: Experience, theory, and predictions. Journal of Management Information Systems, 26(2), 15-42.

Corbin, J and A Strauss (2008). Basics of qualitative research: Techniques and procedures for developing grounded theory. Thousand Oaks, CA, SAGE.

Creswell, JW (2009). Research design: Qualitative, quantitative, and mixed method approaches. Thousand Oaks, CA, Sage Publications Ltd.

Denzin, N (1978). The research act: A theoretical introduction to sociological methods. New York, McGraw-Hill.

Demil, B and X Lecocq (2010). Business Model Evolution: In Search of Dynamic Consistency. Long Range Planning, 43(2-3), 227-246.

Drucker, PF (1954). The Practice of Management. New York: Harper and Row Publishers.

Eisenhardt, KM and ME Graebner (2007). Theory building from cases: Opportunities and challenges. Academy of Management Journal, 50(1), 25-32. 
Eisenhardt, KM (1989). Building Theories from Case Study Research. The Academy of Management Review, 14(4), 532-550.

Elbers, FA (2010). Designing innovative business models: A methodology for structured business model innovation, Master thesis at Eindhoven University of Technology.

Flyvbjerg, B (2006). Five Misunderstandings About Case-Study Research. Qualitative Inquiry, 12(2), 219-245.

Fritscher, B and Y Pigneur (2010). Supporting business model modelling: A compromise between creativity and constraints. TAMODIA 2009, Brussels, Belgium: SpringerVerlag Berlin Heidelberg.

Gambardella, A and AM McGahan (2010). Business-model innovation: general purpose technologies and their implications for industry structure. Long Range Planning, 43(2-3), 262-271.

George, AL and A Bennett (2005). Case Studies and Theory Development in the Social Sciences. Cambridge, MA: MIT Press.

George, G and AJ Bock (2011). The business model in practice and its implications for entrepreneurship research. Entrepreneurship Theory and Practice, 35(1), 83-111.

Gibbs, G. (2007). Analyzing Qualitative Data. London, SAGE.

Hancock, DR and R Algozzine (2006). Doing Case Study Research: A Practical Guide for Beginning Researchers, New York: Teachers College Press.

Jick, TD (1984). Mixing qualitative and quantitative Methods: Triangulation action. Methods and Organisational Research. JS Bateman and TR Ferris. Reston, Reston Publishing: 364-372.

Kim, WC and RA Mauborgne (1997). Value innovation: The strategic logic of high growth. Harvard Business Review, January-February.

Magretta, J (2002). Why business models matter. Harvard Business Review, 80(5), 86-92.

McGrath, R (2010). Business Models: A Discovery Driven Approach. Long Range Panning, 43(2-3), 247-261.

McPhillips, S and O Merlo (2008). Media convergence and the evolving media business model: An overview and strategic opportunities. Marketing Review, 8(3), 237-254.

Miles, MB and MA Huberman (1994). Qualitative data analysis. Thousand Oaks, CA: SAGE.

Mings, SM and PB White (2000). Profiting from online news: The search for viable business models. Internet publishing and beyond: The economics of digital information and intellectual property. B Kahin and HR Varian. Cambridge, MA, MIT Press: 62-95.

Morris, M, M Schindehutte and J Allen (2005). The entrepreneur's business model: Towards a unified perspective. Journal of Business Research, 58, 726-735.

Nadler, D, M Tushman and MB Nadler (1997). Competing by design: the power of organizational architecture. New York, NY: Oxford University Press.

Najmaei A (2011). Dynamic Business Model Innovation: An Analytical Archetype. Proceedings of the $3^{\text {rd }}$ International Conferenceon Information and Financial Engineering (IPEDR), vol 12, Singapore: IACSIT Press. 
OECD (2010). News in the Internet age: New trends in news publishing. Paris, France, OECD.

Osterwalder, A and Y Pigneur (2010). Business Model Generation. Hoboken, NJ: John Wiley \& Sons, Inc.

Osterwalder, A, Y Pigneur and CL Tucci (2005). Clarifying business models: origins, present, and future of the concept. Communications of the Association for Information Systems, 16, 1-25.

Ouden, van E (2012). Innovation Design. London, UK: Springer-Verlag Berlin Heidelberg.

Pateli, AG and GM Giaglis (2004). A Research Framework for Analysing eBusiness Models. European Journal of Information, 13(4), 302-314.

Patton, MQ (2002). Qualitative research and evaluation methods. Thousand Oaks, CA: Sage Publications Ltd.

PriceWaterhouseCoopers (2009). Moving into multiple business models: Outlook for newspaper publishing in the digital age.

Ries, E. (2011). The Lean Start-up. London, England: Potfolio Penguin.

Sosna, M, RN Trevinyo-Rodríguez and SR Velamuri (2010). Business Model Innovation Through Trial-And-Error Learning: The Naturhouse Case. Long Range Planning, 43(2-3), 393-407.

Sperry, R and A Jetter (2009). Theoretical Framework for Managing the Front End of Innovation under Uncertainty, PICMET 2009 Proceedings, Portland, USA.

Stake, RE (2005). Qualitative Case Studies, in N. K. Denzin \& Y. S. Lincoln (eds), The SAGE Handbook of Qualitative Research (3rd ed.), Thousand Oaks, CA: SAGE Publications.

Steenkamp, C, A van der Walt (2004). Web phenomenon applied as ICT platform in support of business model innovation. South African Journal of Information Management, $6(1)$.

Strauss, AL (1987). Qualitative Analysis for Social Scientists, Cambridge, UK: Cambridge University Press.

Teece, DJ (2010). Business Models, Business Strategy and Innovation. Long Range Planning, 43(2-3), 172-194.

The Economist (2006). Who killed the newspaper?

The Economist (2011). Reinventing the newspaper.

Thomke, S, E von Hippel und R Franke (1998). Modes of experimentation: An innovation process - and competitive - variable. Research Policy, 27(3), 315-332.

Trench, B and G Quinn (2003). Online news and changing models of journalism. Irish Communication Review. 9(1).

Tripsas, M and G Gavetti (2000). Capabilities, cognition, and inertia: evidence from digital imaging. Strategic Management Journal, 21(10-11), 1147-1161.

Van der Wurff, R (2005). Print and Online Newspapers in Europe: A Comparative Analysis in 16 Countries. Het Spinhuis.

Yin, R (2002). Case Study Evaluations: A Decade of Progress?, in GF Madaus and DL Stufflebeam (eds), Evaluation Models (2nd ed.), (pp. 185-93), Springer. 
Yin, RK (2009). Case Study Research: Design and Methods (4th ed.), Thousand Oaks, CA: SAGE Publications.

Zott, C and R Amit (2007). Business Model Design and the Performance of Entrepreneurial Firms. Organization Science, 18 (2),181-199.

Zott, C, R Amit and L Massa (2011). The Business Model: Recent Developments and Future Research, Journal of Management, 37 (4), 1019-1042. 
Appendix 1: Changes in the business model resulting from the Internet and related technologies

\begin{tabular}{|c|c|c|}
\hline Recorded changes & Summary & Examples \\
\hline \multicolumn{3}{|l|}{ 1. Value proposition } \\
\hline $\begin{array}{l}\text { Online access to } \\
\text { printed newspaper } \\
\text { content }\end{array}$ & $\begin{array}{l}\text { Readers were offered free online editions of the } \\
\text { following newspapers: Berlingske launched its } \\
\text { online edition in 1998, JP in 1996, and Politiken in } \\
\text { 1998. At the end of } 2010 \text { Berlingske and Politiken } \\
\text { launched their iPad editions, which are identical to } \\
\text { their printed versions and are subscription-based } \\
\text { (JP followed in 2012). }\end{array}$ & $\begin{array}{l}\text { JP: "As one of our subscribers, you can now read your newspaper on the platform of } \\
\text { your choice. In other words, you can both read it on your web browser, in print, and } \\
\text { on your iPhone." } \\
\text { Politiken: "We want to be present [online], even if we have not so far been able to } \\
\text { make money online. We intend to build a [strong] presence, both online and now also } \\
\text { on mobile platforms." }\end{array}$ \\
\hline $\begin{array}{l}\text { The offer of "free" } \\
\text { content }\end{array}$ & $\begin{array}{l}\text { After the introduction to the Internet (1996-1998), } \\
\text { news previously delivered only in paid-for } \\
\text { newspapers became completely free online. }\end{array}$ & $\begin{array}{l}\text { Berlingske: "We have slowly transferred more and more of our journalistic content } \\
\text { [online]. In the beginning it was just news, and then leaders and blogs ... And now we } \\
\text { have transferred more or less all of our professional content." } \\
\text { JP: "Besides print, our online strategy has been to offer our news for free, which } \\
\text { enables us to go after a larger segment [of customers]." }\end{array}$ \\
\hline $\begin{array}{l}\text { New types of content, } \\
\text { genres and media } \\
\text { technologies; media } \\
\text { convergence }\end{array}$ & $\begin{array}{l}\text { New Internet technologies allowed newspapers to } \\
\text { start experimenting with other journalistic genres, } \\
\text { e.g. radio (e.g. jptv.dk since 2005) and TV (e.g. } \\
\text { jptv.dk since 2000), and combine them on a digital } \\
\text { platform. All three newspapers have their own web } \\
\text { TV production, while JP also runs an Internet radio. }\end{array}$ & $\begin{array}{l}\text { Politiken: "Sound and images are essential ingredients in our digital delivery. After } \\
125 \text { years of dealing with the written word, it's a big step to suddenly have to learn to } \\
\text { communicate through sound and images." } \\
\text { Berlingske: "We have to satisfy people who want content on all platforms and media } \\
\text { types. This is our ambition." }\end{array}$ \\
\hline $\begin{array}{l}\text { Support of the overall } \\
\text { brand, not just the } \\
\text { printed newspaper }\end{array}$ & $\begin{array}{l}\text { The newspapers shifted focus from the market } \\
\text { positioning of their printed editions to supporting } \\
\text { the overall brand regardless of the delivery } \\
\text { platform. }\end{array}$ & $\begin{array}{l}\text { JP: "We want to be a media house with a common denominator, which is our brand. } \\
\text { And that's what we are doing as fast as possible. This is why we are getting into both } \\
\text { radio and online news delivery, and into so many other different niches [...] We say } \\
\text { that our [main] asset is our brand, and this is at the top of all our activities here." } \\
\text { Politiken: "Over the last ten years we have moved strategically from being an } \\
\text { omnibus newspaper ... to being more of a "brand" company, which takes its target } \\
\text { audience extremely seriously." }\end{array}$ \\
\hline $\begin{array}{l}\text { New online products } \\
\text { (specialized and niche ) } \\
\text { and apps for the web, }\end{array}$ & $\begin{array}{l}\text { Apart from offering printed editions online and free } \\
\text { news, newspapers started experimenting with } \\
\text { various specialized paid-for offerings on their }\end{array}$ & $\begin{array}{l}\text { Berlingske: "We are also developing new ways to sell content, [e.g.] we've developed } \\
\text { an info shop on our website where you can buy content that we've put together in } \\
\text { new interesting ways ... It can be data-based content or other. This is an area we will }\end{array}$ \\
\hline
\end{tabular}




\begin{tabular}{|c|c|c|}
\hline Recorded changes & Summary & Examples \\
\hline $\begin{array}{l}\text { smart phones and } \\
\text { tablet computers }\end{array}$ & $\begin{array}{l}\text { webpages and special apps for smart phones and } \\
\text { tablets. }\end{array}$ & $\begin{array}{l}\text { be focusing on more and more in the future." } \\
\text { JP: "The Mediawatch - our niche product - is for mass media professionals, and } \\
\text { includes things of interest to them, e.g. job ads, etc. We have also introduced } \\
\text { Finanswatch for bankers and others with similar interests. [...] This is a clear path we } \\
\text { are on now." }\end{array}$ \\
\hline $\begin{array}{l}\text { Online advertising } \\
\text { space and channels for } \\
\text { marketers and } \\
\text { advertisers }\end{array}$ & $\begin{array}{l}\text { The newspapers have actively sold their new digital } \\
\text { space to marketers and advertisers since } 2000 \text {. }\end{array}$ & $\begin{array}{l}\text { Berlingske: "We are constantly developing not just journalistic content, but also } \\
\text { commercial content, so that we can continue to be the medium that brings attractive } \\
\text { advertisers in contact with the most attractive readers." } \\
\text { JP: "We think that our advertisers are interested in being in an environment where } \\
\text { people are closer to a purchase process than just wanting to read news about cars. } \\
\text { And we have seen this in a wide variety of areas, primarily in classified areas, i.e. } \\
\text { cars, boats, music." }\end{array}$ \\
\hline $\begin{array}{l}\text { Consumer goods } \\
\text { through e-commerce } \\
\text { websites }\end{array}$ & $\begin{array}{l}\text { Berlingske and Politiken have both launched e- } \\
\text { commerce sites where they recommend and sell } \\
\text { selected third-party goods and advertise special } \\
\text { offers. These include "reader" shops, such as } \\
\text { PolitikenPlus by Politiken, and Lidtmere by } \\
\text { Berlingske. }\end{array}$ & $\begin{array}{l}\text { Berlingske: "We have an additional presence [online] where we sell not only } \\
\text { journalistic products, but also other products, e.g. wine, tours, firewood." } \\
\text { Politiken: "We have set up an additional [e-]business which we have called } \\
\text { PolitikenPlus. We are extremely selective about the type of products we have there. } \\
\text { [...] Each product is chosen in a way that reflects and supports our values." }\end{array}$ \\
\hline \multicolumn{3}{|c|}{ 2. Changes in customer segments } \\
\hline $\begin{array}{l}\text { Fragmentation of the } \\
\text { reader segment }\end{array}$ & $\begin{array}{l}\text { Changes in the newspaper value proposition, } \\
\text { combined with competition from other media } \\
\text { sources, has led to a decreasing number of } \\
\text { traditionally loyal and paying readers (e.g. in } 2012 \\
\text { printed editions were preferred only by the over- } 45 \\
\text { reader segment). On the other hand, newspapers } \\
\text { targeted increasing numbers of broadly defined and } \\
\text { mostly non-paying customer segments online and } \\
\text { mobile, which are generally young and fast- } \\
\text { moving. }\end{array}$ & $\begin{array}{l}\text { Berlingske: "We have clearly much more loyal customers for print... " } \\
\text { Politiken: "Our share of customers in the socio-graphic target audience is the same, } \\
\text { regardless of platform, but there are significant differences in the demographic } \\
\text { profiles of our customers on our various platforms. Basically, the more modern the } \\
\text { platform, the younger our customers. It is therefore good for us to get onto new } \\
\text { platforms because they are a recruitment base for new customers." }\end{array}$ \\
\hline
\end{tabular}




\begin{tabular}{|c|c|c|}
\hline Recorded changes & Summary & Examples \\
\hline $\begin{array}{l}\text { New multiple business- } \\
\text { to-business customers }\end{array}$ & $\begin{array}{l}\text { The newspapers acquired diverse business-to- } \\
\text { business customers for their content, including } \\
\text { Internet portals, TV and cable TV companies with } \\
\text { news feeds and companies with special interests. }\end{array}$ & $\begin{array}{l}\text { JP: "If, for example, company } \mathrm{N} \text { wants to create activity on their website or in their } \\
\text { app, they can buy a feed from us which is primarily focused on environmental and } \\
\text { wind energy, or the pharmaceutical industry [ ...], etc. It is business to business..." } \\
\text { Berlingske: "We have, for example, created a partnership with Microsoft about } \\
\text { something called 'GoNews', where we provide content, and they deliver technology. } \\
\text { So I think we should collaborate more with technology companies." }\end{array}$ \\
\hline \multicolumn{3}{|c|}{ 3. Changes in communication and distribution channels } \\
\hline $\begin{array}{l}\text { Multiple, as opposed to } \\
\text { single (e.g. printed } \\
\text { newspapers), delivery } \\
\text { channels }\end{array}$ & $\begin{array}{l}\text { The newspapers started using multiple novel online } \\
\text { delivery channels like websites, Facebook, Twitter, } \\
\text { blogging, video, online TV-channels, local radio } \\
\text { stations and apps rather than the previous single } \\
\text { channel - the printed newspaper delivered to the } \\
\text { door - making distribution more complex. }\end{array}$ & $\begin{array}{l}\text { Politiken: "Our job - and in reality it is our totally dominant business model - is to be } \\
\text { the preferred news brand of the target group, not just the preferred newspaper. So our } \\
\text { job is to offer information to our target group on those platforms where it prefers to } \\
\text { receive it." } \\
\text { Berlingske: "You can read Berlingske in print, on the web, and on a mobile phone - } \\
\text { including a wap mobile. And we also have a special Business edition for the iPhone } \\
\text { and iPad, and you can also read the newspaper in digital format on the iPhone and } \\
\text { iPad, a kind of e-paper, which you can purchase and turn pages, like in a real } \\
\text { newspaper." }\end{array}$ \\
\hline $\begin{array}{l}\text { Lost ownership of } \\
\text { delivery channels and } \\
\text { distribution of content } \\
\text { to third-party channels }\end{array}$ & $\begin{array}{l}\text { With the move to multiple digital platforms, the } \\
\text { newspapers started using the delivery channels of } \\
\text { various digital media, which they neither had } \\
\text { control over nor ownership. }\end{array}$ & $\begin{array}{l}\text { Berlingske: "Before [...], we controlled the distribution, publishing and content. Now } \\
\text { we only have the content left, since Google or Apple are responsible for the } \\
\text { distribution [...] But how are we going to earn money if we only have content?" } \\
\text { Politiken: "The fact that Facebook has the copyright for everything that has been } \\
\text { uploaded, it is difficult to create a journalistic product. And since it states on page } 13 \\
\text { of their conditions [i.e. user license agreement] that they have the right to sell it to } \\
\text { third parties, it is also difficult to upload journalistic content." }\end{array}$ \\
\hline \multicolumn{3}{|c|}{ 4. Change in the relationships with customers } \\
\hline $\begin{array}{l}\text { Two-way } \\
\text { communication and } \\
\text { deepening cooperation } \\
\text { with readers }\end{array}$ & $\begin{array}{l}\text { Web } 2.0 \text { enabled the newspaper to establish an } \\
\text { ongoing dialogue with their readers. Among other } \\
\text { things, this allowed them to collect crowdsourcing } \\
\text { information, build customer loyalty, and develop } \\
\text { new offerings. }\end{array}$ & $\begin{array}{l}\text { JP / Politiken: "We are totally convinced that the development of new products is } \\
\text { most successful if we have strong relationships, and strong units which are in close } \\
\text { contact with their specific customers. The products which we launch should be } \\
\text { created together with consumers." }\end{array}$ \\
\hline
\end{tabular}




\begin{tabular}{|c|c|c|}
\hline \multicolumn{3}{|c|}{ 5. Changes in revenue streams } \\
\hline $\begin{array}{l}\text { Continuous } \\
\text { experimentation with } \\
\text { the pricing of digital } \\
\text { products }\end{array}$ & $\begin{array}{l}\text { The newspapers found that online advertising could } \\
\text { not cover the costs of content production and give } \\
\text { them the revenues they hoped for. Eventually, they } \\
\text { all realised the need to move from free to fee for } \\
\text { online content and separation of access to paid and } \\
\text { unpaid content. As a result, the newspapers started } \\
\text { experimenting with various revenue models. }\end{array}$ & $\begin{array}{l}\text { Politiken: "We can experiment with payments [for online content], such as we have } \\
\text { done for our iPhone app, and try to find out what our users are willing to pay. To test } \\
\text { this, we have started with a monthly subscription of } 1.60 € . " \\
\text { "We have chosen a freemium model for many of our apps, which means limited } \\
\text { access to content when it is downloaded free, and more [content] if you pay for it." }\end{array}$ \\
\hline $\begin{array}{l}\text { Changes in the revenue } \\
\text { structure of the printed } \\
\text { newspaper }\end{array}$ & $\begin{array}{l}\text { A lot of advertising revenue has moved from } \\
\text { printed newspapers to online media, which has } \\
\text { resulted in a dramatic decrease in advertising } \\
\text { revenues of the former and a change in their } \\
\text { revenue structure. }\end{array}$ & $\begin{array}{l}\text { Berlingske: "The traditional distribution of revenue for a newspaper }-60 \% \text { from } \\
\text { advertising, } 40 \% \text { from subscriptions, or } 50-50 \text { for some - does not exist any more, } \\
\text { because advertising is moving to digital platforms, and advertising revenues from } \\
\text { print have fallen dramatically, especially from classifieds, in recent years. The time } \\
\text { when you could rely on advertising revenue as the primary source of income is over. } \\
\text { [...] Digital and other types of revenue are going to play a larger role." } \\
\text { JP: "Clearly, when you look at our ability to monetize digital content, it is not nearly } \\
\text { as good as for print." }\end{array}$ \\
\hline $\begin{array}{l}\text { Revenues from non- } \\
\text { core activities }\end{array}$ & $\begin{array}{l}\text { To compensate for the loss of revenues from } \\
\text { printed ads, the newspapers looked at different } \\
\text { possibilities outside their core competence of } \\
\text { producing journalistic content, such as sales of } \\
\text { consumer goods and e-commerce. These revenues } \\
\text { are used to support the production and delivery of } \\
\text { the newspapers' content. }\end{array}$ & $\begin{array}{l}\text { Berlingske: "We have sweet deals and other things that you could call non- } \\
\text { traditional revenues. So, the more we can earn there to finance our core business, i.e. } \\
\text { journalism and content, the better. And if we can link it together, then that is even } \\
\text { better." } \\
\text { Politiken: "We have PolitikenPlus, which sells physical products [...], and which has } \\
\text { a turnover of around of } 5.5 \text { million } €[\ldots] \text {. This is a significant business for us }[\ldots] \text {. } \\
\text { And we come up with new areas of business around the brand all the time. We must! } \\
\text { We've been on } 2 \text { legs so far, and now it's gone up to } 3 \text {, and we have to achieve 4-5-6- } \\
7 \text { legs. We must work constantly to develop new sources of income." }\end{array}$ \\
\hline \multicolumn{3}{|c|}{ 6. Changes in the constitution of key resources } \\
\hline $\begin{array}{l}\text { New IT resources } \\
\text { required }\end{array}$ & $\begin{array}{l}\text { Naturally, producing and delivering newspapers } \\
\text { and various content on multiple digital platforms } \\
\text { requires investments in IT and human resources. }\end{array}$ & $\begin{array}{l}\text { JP / Politiken: "You suddenly realise that you also need someone who can program, } \\
\text { say, iPhone applications. In the media group, we have } 40-50 \text { full-time employees } \\
\text { with a background in IT, i.e. programmers. So we have quite a taskforce for the IT } \\
\text { [part]." }\end{array}$ \\
\hline $\begin{array}{l}\text { New types of } \\
\text { journalists and } \\
\text { communication }\end{array}$ & $\begin{array}{l}\text { Digital content and platforms put pressure on } \\
\text { journalists and newspaper managements to add new } \\
\text { journalistic and communication skills and adjust to }\end{array}$ & $\begin{array}{l}\text { Berlingske: "We have hired four new people with special digital skills, because our } \\
\text { organisation could not find them internally [...]. This included everything, from real- } \\
\text { time blogging to embedding, using Google maps in articles, and web TV spots, to }\end{array}$ \\
\hline
\end{tabular}




\begin{tabular}{|c|c|c|}
\hline workers & $\begin{array}{l}\text { the requirements of the new media. Newer } \\
\text { initiatives, like the use of social media, have also } \\
\text { created novel communication needs, e.g. } \\
\text { community management. }\end{array}$ & $\begin{array}{l}\text { mixing communication genres naturally online." } \\
\text { JP / Politiken: "We are getting to the point where we to a larger extent will employ } \\
\text { journalists with a technological background [...]. So we often search for talent in the } \\
\text { IT University, or among people with a background in digital media." }\end{array}$ \\
\hline \multicolumn{3}{|c|}{ 7. Changes in key activities } \\
\hline $\begin{array}{l}\text { New organizational } \\
\text { structures for } \\
\text { producing and } \\
\text { publishing }\end{array}$ & $\begin{array}{l}\text { Producing and delivering news and other content } \\
\text { both online and in print has led to the } \\
\text { reorganisation of the newspapers' formal } \\
\text { organization. }\end{array}$ & $\begin{array}{l}\text { Politiken: "We have an editorial staff of over } 25 \text { journalists, working exclusively for } \\
\text { our online newspaper, for our mobile platform, and our led-display newspaper. } \\
\text { They're devoted, and are also evaluated on it." } \\
\begin{array}{l}\text { Berlingske: "The web was what largely guided the organizational changes we made } \\
\text { to our editorial staff, where we have just completed another change. [...] We have } \\
\text { organised our editorial staff in different ways. I think we've had three organizational } \\
\text { changes over the last } 2-3 \text { years, so that we can constantly stay abreast of things." }\end{array}\end{array}$ \\
\hline \multicolumn{3}{|c|}{ 8. Changes in the selection of key partners } \\
\hline $\begin{array}{l}\text { New partnerships with } \\
\text { Information and } \\
\text { Communication } \\
\text { Technology (ICT) } \\
\text { partners }\end{array}$ & $\begin{array}{l}\text { Historically, newspapers have largely relied on } \\
\text { their partners for distribution and print. With } \\
\text { constantly emerging Internet technologies, } \\
\text { however, they found themselves dependent on } \\
\text { companies that could provide the right set of ICT } \\
\text { capabilities and service. }\end{array}$ & $\begin{array}{l}\text { Berlingske: "We have outsourced our IT and our entire IT maintenance to company } \\
\text { NN, but I also believe that we are going to work [with them] in the editorial field. } \\
\text { Well, I could go through an entire portfolio of partners that we have on different } \\
\text { platforms and with different products, etc., and it is [...] completely different from } \\
\text { just a few years ago." } \\
\text { JP: "It is pretty clear that we will rely more on external products. [...] We have a } \\
\text { group of programmers in the Ukraine who give life to our products." }\end{array}$ \\
\hline $\begin{array}{l}\text { Cooperation with Web } \\
\text { portals and news } \\
\text { aggregators }\end{array}$ & $\begin{array}{l}\text { The newspapers tried to establish collaborative } \\
\text { relationships with their strongest competitors } \\
\text { online, i.e. news aggregators and online portals. }\end{array}$ & $\begin{array}{l}\text { Berlingske: "Large technology companies mainly make money on the technology } \\
\text { around our content, and this is a big challenge for us. For example, we have } \\
\text { established a partnership with Microsoft over something called 'GoNews', where we } \\
\text { provide the content and they deliver the technology." } \\
\\
\text { JP / Politiken: "We work, for example, with eBay, with whom we collaborate on ads. } \\
\text { So there is a fairly strong development on that front." }\end{array}$ \\
\hline
\end{tabular}




\begin{tabular}{|l|l|l|}
\hline $\begin{array}{l}\text { Cost reduction through } \\
\text { elimination of obsolete } \\
\text { or less profitable } \\
\text { operations }\end{array}$ & $\begin{array}{l}\text { Faced with falling revenues and a shrinking } \\
\text { readership base, newspapers have evaluated their } \\
\text { activities and products and cut costs where possible. } \\
\text { This included eliminating badly performing } \\
\text { products and arrangements. }\end{array}$ & $\begin{array}{l}\text { Berlingske: "As far as our printed newspapers are concerned, we have had a falling } \\
\text { circulation for at least the last 10 years. It's partly a controlled fall - we've eliminated } \\
\text { a number of subscription plans which were unprofitable for us." }\end{array}$ \\
\hline
\end{tabular}

